\title{
3: $170346795-170285252$
}

National Cancer Institute

\section{Source}

National Cancer Institute. 3: 170346795-170285252. NCI Thesaurus. Code C42224.

Physical location of EVI1_Gene 